\title{
Exchange Rate Fluctuations, Financing Constraints, Hedging, and Exports: Evidence from Firm Level Data ${ }^{*}$
}

\author{
Robert Dekle \\ Heajin Ryoo \\ Department of Economics \\ University of Southern California
}

November 2002

\begin{abstract}
An important puzzle in international macroeconomics is the exchange rate disconnect puzzle. Nominal exchange rates seem to be unrelated to other macroeconomic variables, for example, export quantities. This paper uses Japanese firm level data to examine whether exchange rate fluctuations are strongly related to the export quantities of firms. We build a simultaneous nonlinear structural model with external financing costs, and estimate the model on 14 separate Japanese 4 digit level industries. We find that export volumes at the firm level are significantly affected by exchange rate fluctuations. We find higher elasticit ies of exports with respect to exchange rates than in previous work. Our results cast some doubt on the prevailing wisdom that exchange rates have no effect on trade. Finally, we find in our data that financing constraints play an important role in affecting the sensitivity of exports to exchange rate fluctuations. Firms that are less financially constrained -for example, keiretsu firms - tend to have lower exchange rate elasticities, which is consistent with our model.
\end{abstract}

\footnotetext{
* We thank Caroline Betts, Hyeok Jeong, Yong Kim, Roger Moon, and Aris Protopapadakis, for very helpful comments on a previous draft. We also thank the Development Bank of Japan in providing the data.
} 


\section{Introduction}

After nearly three decades of exchange rate floating among industrialized countries there is yet to emerge a consensus among academic economists regarding the impact of exchange fluctuations on real economic variables. The traditional view is that fluctuations in exchange rates affect relative domestic and foreign prices, causing expenditures to shift between domestic and foreign goods (Orcutt, 1950; Goldstein and Khan, 1985; Obstfeld, 2002). The new view is that relative prices are not much affected by exchange rate fluctuations in the short-run (see Obstfeld, 2002, and Engel, 2002 for reviews), thus muting expenditure shifts. The new view is buttressed by a recent empirical literature (e.g. Mussa, 1986; Baxter and Stockman; 1989, Flood and Rose, 1995) showing that high exchange rate volatility under floating exchange rates is not related to the high volatility of other macroeconomic variables.

In contrast to this debate among academic economists, businesspeople appear convinced that exchange rate fluctuations have real effects. Executives, especially of exporting firms, agonize over declining exports when their home currency appreciates in nominal terms. They expend much time and resources planning hedging strategies, to lessen the impact of exchange rate fluctuations on their exports. They also expend much time and resources lobbying policymakers, to persuade them to stabilize currencies, either by intervening in foreign exchange markets, or by more extreme measures such as fixing exchange rates. ${ }^{1}$

\footnotetext{
${ }^{1}$ Frankel (1984) gives a vivid description of Lee Morgan, chairman of Caterpillar Tractor, who came to Washington in 1983 to argue that the cheap yen is making price competition with the Japanese impossible. Morgan and other business executives pressed the U.S. administration to take measures to depreciate the dollar vis -à-vis the yen. One measure was to make buying yen assets easier so as to raise international demand for the currency.
} 
However, there is little systematic research, examining whether exchange rates affect real quantities at the microeconomic or firm level. ${ }^{2}$ This paper fills the void by examining whether exchange rate fluctuations influence the export volumes of firms. We find that export volumes at the firm level are significantly affected by exchange rates. Depending on the industry, a one percent appreciation of the domestic currency results in an average decline in export volumes of 0.02 to 2.9 percent. These elasticities are generally higher than what are found in previous work, using aggregate data. Moreover, these high elasticities persist, despite evidence of considerable hedging of exchange rate risk. Our results, however, support the findings of other work that also used sectoral or micro-level data. ${ }^{3}$

We build a structural model of the exporting firm, in Cournot competition with the foreign firm in foreign markets. The exporting firm uses its cash flow and borrows from the external financial markets, to produce goods for export; financing costs are increasing with additional amount of external borrowing. The firm's cash flow is exposed to shocks that also cause the exchange rate to fluctuate. Our model is microeconomic or partial equilibrium in nature; we carefully model the response of firms to the aggregate shock, but do not embed our model in general equilibrium.

We estimate our model of the exporting firm using Japanese firm level data from 1982

\footnotetext{
${ }^{2}$ There is a growing literature examining international trade theories at the firm level (Bernard, Eaton, Jensen, and Kortum, 1999; Bernard and Jensen, 2001). However, with the exception of Das, Roberts, and Tybout (2001) this literature has not focused on how exchange rates affect export quantities. Das, Roberts, and Tybout (2001) are interested in the export supply response to an exchange rate change on two margins: entry into and exit from export markets; and export production adjustment among incumbents. Their paper is not concerned with the effects of financing constraints on export quantities, a key concern of this paper. Moreover, while our sample covers over 90 percent of Japanese manufacturing exports, their sample coverage is more limited (Columbian chemicals industry). Forbes (2002) examined the impact of large devaluations on the export sales of over 13,000 firms in developing countries. She finds that on average export sales improve by 4 percent, one year after the devaluation episodes. Her work is similar to ours in that she is concerned about how financial variables affect export performance. There is also a larger literature examining the effect of exchange rate changes on corporate profitability, or corporate exposure. See Dekle (2001) and Dominguez and Tesar (2001) for a review of the recent literature on corporate exposure.

${ }^{3}$ Exchange rates were found to affect real quantities, such as labor demand. See Gourinchas (1999) and Goldberg and Tracy (1999).
} 
to 1997 , for 105 firms in the 14 largest export industries at the 4-digit level. We find that our model of the exporting firm fits the data remarkably well. We find that shocks to the firm's cash flows or balance sheets have significant real effects. From the estimated parameters of our model, we calculate the elasticity of export volumes to exchange rate changes, and find large elasticities for many industries.

What explains our high estimated export elasticities with respect to exchange rates? One explanation given for the small estimated export elasticities in the previous literature is that prices are sticky in the buyer's currency (Goldberg and Knetter, 1998; Betts and Devereux, 2000). Since buyer currency prices are sticky, exchange rate changes become powerless in altering the relative prices foreign consumers face, thus limiting changes in trade flows. From our estimates, we also find that export prices in terms of the buyer's currency are sticky. Thus, the increased responsiveness of exports to exchange rate fluctuations in our model is not induced by changes in international relative prices.

Rather, in our model, the responsiveness of exports to exchange rate fluctuations arises from a loosening of balance sheet constraints. Suppose that a depreciation in the exporter's currency is positively correlated with a relaxation of financ ing constraints. With relaxed balance sheet constraints, the exporter with a depreciating currency is then simply able to produce more, for export, regardless of the inflexibility of foreign prices.

In most industries in our sample -10 out of 14 industries- a currency depreciation is correlated with a relaxation of financing constraints. For these industries, a currency depreciation will be related to a strong expansion in exports, through the relaxation of balance sheet constraints. There are 4 industries in which a currency depreciation is correlated with a tightening of financing constraints. However, firms in these industries are able to substantially offset the adverse impact on balance sheets of aggregate shocks 
through hedging activities. Thus, we observe a positive relationship between a currency depreciation and exports, even in these industries.

This paper relates to two literatures. The first is the literature examining the impact of exchange rates on export volumes. This literature is vast, but most of the earlier studies estimated export elasticities using either time series data for one country, or data for a cross-section of countries (see Deardorff, 1984, and Hooper, Johnson, and Marquez, 1998 for reviews). Most studies using data until the mid-1980s have found statistically significant, but small exchange rate elasticities (e.g., Gotur, 1985; Cushman, 1986; Thursby and Thursby, 1987). The most recent empirical studies have tended to find insignificant effects of exchange rate levels, or volatilities on export volumes (Pozo, 1992; Chowdhury, 1993; Parley and Wei, 1993). In fact, much recent international macroeconomic research has focused on explaining this exchange rate disconnect puzzle, or why exchange rates have no effect on real variables such as exports, and GDP growth in industrialized countries (Obstfeld, 2002; Engel, 2002).

Our findings of large and significant export elasticities imply that there is no exchange rate disconnect at the firm level. Since our sample of Japanese exporters covers over 90 percent of total Japanese manufacturing exports, the discrepancy between the results obtained at the aggregate level and at the firm level is not simply an artifact of incomplete sample coverage. Rather, the discrepancy suggests that it may be important to include financing constraints and potentially other non-linearities, when modeling the relationship between exchange rates and export volumes. ${ }^{4}$

\footnotetext{
${ }^{4}$ Using aggregate data, Pozo (1992) and Chowdhury (1993) find that the relationship between exchange rate volatilities and export volumes are significantly negative in a nonlinear specification. However, they do not explicitly model how financing constraints affect the relationship between exchange rates and export volumes.
} 
The second literature related to the current study is that of hedging exchange rate risk under financing constraints. The seminal theoretical paper in this area is Froot, Scharfstein, and Stein (1993), who show that the correlation between the investment opportunities and the availability of cash flows is the main determinant of hedging. When exchange rates and the shocks to cash flows are positively correlated, a firm will hedge less than completely or not at all, since when export opportunities are greatest -that is, when the currency is depreciated-cash flow and export production will automatically be high. When exchange rates and cash flow shocks are negatively correlated, a firm will hedge completely, since when the currency is depreciated, cash flows will also tend to be low. In fact, a firm may enter into hedging contracts that reverse the negative correlation between a currency depreciation and cash flows. For example, by engaging in foreign currency lending, a firm can increase its domestic currency cash flows, when the domestic currency is depreciating. We perform one of the first formal tests of the Froot, Scharfstein, and Stein (1993) model, and find that their model fits the data remarkably well. ${ }^{5}$

The main difficulty in testing theories of foreign exchange hedging behavior at the firm level is the unavailability of comprehensive hedging data. Firms can hedge currency risk in a myriad of ways (Bartov and Bodnar, 1994). For example, a firm can lend internationally, building in a positive correlation between exchange rates and cash flow shocks. Firms can also hedge operationally, by engaging in foreign direct investment in export markets, thereby having production costs and revenues in the same currency (Allayannis and Ofek, 2001; Baba and Fukao, 2000). While data on foreign currency forward and option contracts

\footnotetext{
${ }^{5}$ Other recent applications of the Froot, Scharfstein, and Stein (1993) model are Allayannis and Mozumdar (1999) and Aguiar (2001). Allayannis and Mozumdar (1999) find that firms use foreign currency derivatives to reduce the volatility of net cash flows. Aguiar (2001), examining the foreign currency debts of Mexican firms before and after the peso crisis of 1994, finds that expanding firms tend to borrow disproportionally in foreign currency before the devaluation.
} 
may be available, comprehensive firm level data on foreign currency borrowing and foreign direct investment are difficult to obtain. To get around this problem of incomplete data coverage, we can - using our model- simulate the hypothetical export elasticities that would arise if the firm hedged completely. By comparing these hypothetical export elasticities with our estimated export elasticities, we can infer the degree of hedging by our sample of firms. We find that Japanese exporters indeed hedge currency risk. As our theory predicts, firms hedge less in industries in which an exchange rate depreciation is correlated with loosening financing constraints. In industries in which a currency depreciation is correlated with tightening financing constraints, firms hedge more, to ins ulate their cash flows from exchange rate shocks.

This paper is organized as follows. In the next Section, we develop our structural model of financing, hedging, and export volumes at the firm level. Section III describes the estimation specification and the data. Section IV presents and discusses the estimation results, and Section V concludes. 


\section{The Model: Financing Constraints, Hedging and Export Quantities}

Our model of the exporting firm emphasizes competition with the foreign firm and

financing constraints. ${ }^{6}$ We model an exporting firm whose internal cash flow is exposed to shocks that also cause the exchange rate to fluctuate. The firm uses its cash flow, and borrows from external financial markets, to produce goods for export. The firm faces financing costs that increase with the amount of external borrowing. With regards to the competitive structure in the export market, the exporting firm competes with the foreign firm in classic duopoly fashion.

We now develop the model more formally. Assume there are two countries, foreign and domestic, each with one firm. The firm in the domestic country produces the good $X$ only for export to the foreign market, and the foreign firm produces the same good $X$, but only for its own market. ${ }^{7}$

We assume that each firm uses only domestic inputs for its production. At period $t$, the domestic exporting firm and the foreign firm produce $X_{t}^{E}, X_{t}^{F}$ units respectively of the good $X$ at price $P$ in the foreign or buyer's currency. We assume that the domestic firm uses its expected cash flow to produce goods for export, and that this expected cash flow is affected

\footnotetext{
${ }^{6}$ Our model's assumptions are standard and are from Froot, Scharfstein, and Stein (1993), which is the seminal paper on hedging with imperfect capital markets.

${ }^{7}$ We do not model the entry of non-exporters into and the exit of exporters from export markets. Rather we focus on export volume adjustment among incumbents. First, in our sample of 105 Japanese exporters from 1982 to 1997, there is not one case of exit from exp ort markets. Since our sample of exporters are companies listed on the stock exchanges, there are no small firms that typically account for the bulk of exiting and entry firms. Second, the export volume response to an exchange rate change is typically driven by the adjustment of existing exporters, rather than by new entry or exit. This is because new entrants are typically much smaller than incumbents. These new entrants are also most likely to exit. For example, Das, Roberts, and Tybout (2001) show in their simulations of the Columbian chemical industry, that in a 10 percent devaluation of the peso, over 90 percent export revenue is drawn by the expansion of existing exporters.
} 
by shocks that also cause the exchange rate to fluctuate. The firm can finance internally or externally to produce the good $X$ in period $t$ :

$$
C_{t}^{j} X_{t}^{j}=v_{t}^{j}+w_{t}^{j}, \quad \text { where } j=E, F
$$

where $C_{t}^{j}$ is the marginal cost of production, and $w_{t}^{j}$ is the amount of expected cash flow during the period $t$ and $v_{t}$ is the amount that the firm needs to finance externally in period $t$.

We assume that raising external funds is costly. Specifically, we assume that the marginal cost of external financing increases with the amount of external financing, that is, the external financing constraint, $C(v)$, is a convex function of the size of external financing. The profits of foreign and domestic firms can be written as:

$$
\begin{aligned}
& \Pi_{t}^{F}=P_{t} X_{t}^{F}-C_{t}^{F} X_{t}^{F}-C\left(v_{t}^{F}\right) \\
& \Pi_{t}^{E}=e_{t} P_{t} X_{t}^{E}-C_{t}^{E} X_{t}^{E}-C\left(v_{t}^{E}\right)
\end{aligned}
$$

where, $\prod_{x}>0$, and $\prod_{x x}<0$, and $e_{t}$ is the price of foreign currency in terms of the domestic currency at period $t$.

The external financing constraint of the domestic and foreign firm are:

$$
C\left(v_{t}^{j}\right)=\left(C_{t}^{j} X_{t}^{j}-w_{t}^{j}\right)^{\beta}, \quad \text { where } j=E, F
$$

A high $\beta$ implies that external lenders demand a high premium for every additional unit of outside financing. Since the risk of defaulting of a firm increases with its debt, the cost of financing should increase with additional external financing, implying $\beta>1$. 
The domestic exporting firm maximizes its expected profit ${ }^{8}$ :

$$
\underset{X_{t}^{E}}{\operatorname{Max}} \Pi_{t}^{E}=\operatorname{Max}\left\{e_{t} P_{t} X_{t}^{E}-C_{t}^{E} X_{t}^{E}-C\left(v_{t}^{E}\right)\right\}
$$

For simplicity, we assume that the foreign firm's external financing cost is constant, i.e. $C\left(v_{t}^{F}\right)=\mathrm{c}$. Thus the foreign firm maximizes its expected profit:

$$
\underset{X_{t}^{F}}{\operatorname{Max}} \Pi_{t}^{F}=\operatorname{Max}\left\{P_{t} X_{t}^{F}-C_{t}^{F} X_{t}^{F}-c\right\}
$$

Finally, we assume that the demand curve for good $X$ in the export market is linear:

$$
P_{t}=a-b\left(X_{t}^{E}+X_{t}^{F}\right)
$$

where $a$ and $b$ are parameters.

From the first order conditions of the profit maximization problem, we get the following reaction functions for the foreign and domestic firms:

$$
\begin{aligned}
& X_{t}^{F}=\frac{a-C_{t}^{F}-b X_{t}^{E^{*}}}{2 b} \\
& X_{t}^{E}=\frac{1}{2 b}\left(a-b X_{t}^{F^{*}}-\frac{C_{t}^{E}}{e_{t}}-\beta\left(C_{t}^{E} X_{t}^{E}-w_{t}^{E}\right)^{\beta-1} \frac{C_{t}^{E}}{e_{t}}\right)
\end{aligned}
$$

In Cournot-Nash equilibrium, the equilibrium price in the foreign market is given by:

\footnotetext{
${ }^{8}$ The theoretical framework implicitly assumes that the domestic exporting firm is also engaged in Cournot competition with other domestic exporting firms. If domestic exports are approximately equal sized, then the reaction functions (7) and (8), and the expressions for equilibriumproduction, (10) and (11) remain unchanged (See Bresnahan, 1987).
} 


$$
\begin{aligned}
P_{t}^{*} & =a-b\left(X_{t}^{E^{*}}+\frac{a-C_{t}^{E}-b X_{t}^{E^{*}}}{2 b}\right) \\
& =\frac{1}{2}\left(a-b X_{t}^{E^{*}}+C_{t}^{F}\right)
\end{aligned}
$$

The equilibrium productions of $\operatorname{good} X$ for the foreign and domestic firms are given by:

$$
\begin{aligned}
& X_{t}^{F^{*}}=\frac{1}{3 b}\left[a-2 C_{t}^{F}+\frac{C_{t}^{E}}{e_{t}}+\beta\left(C_{t}^{E} X_{t}^{E^{*}}-w_{t}^{E}\right)^{\beta-1} \frac{C_{t}^{E}}{e_{t}}\right] \\
& X_{t}^{E^{*}}=\frac{2}{3 b}\left[\frac{a}{2}+\frac{C_{t}^{F}}{2}-\frac{C_{t}^{E}}{e_{t}}-\beta\left(C_{t}^{E} X_{t}^{E^{*}}-w_{t}^{E}\right)^{\beta-1} \frac{C_{t}^{E}}{e_{t}}\right]
\end{aligned}
$$

When the domestic currency depreciates, the relative cost of the domestic firm falls. This situation would be favorable for the domestic firm, but not for the foreign one. Therefore, the domestic firm would prefer to increase its exports when its currency is depreciated. However, the domestic firm cannot expand its export production if the firm's external financing is constrained.

\section{The External Financing Constraint}

Since the domestic firm's production for exports depends on its internal cash flows, random fluctuations in cash flows reduce the expected profits of the firm, if the profit function, $\Pi(w)$ is increasing and concave in $w$.

Let $F(x)$ be the net profit function of the domestic firm without external financing constraints, which is increasing and concave in $X$, i.e. $F_{x}>0, F_{x x}<0$, we get; 


$$
\begin{aligned}
& \Pi_{w}=F_{X} \frac{d X_{t}^{E^{*}}}{d w_{t}^{E}}-C_{v}\left(\frac{d X_{t}^{E^{*}}}{d w_{t}^{E}}-1\right)>0 \\
& \Pi_{w w}=F_{X X}\left(\frac{d X_{t}^{E^{*}}}{d w_{t}^{E}}\right)^{2}-C_{v v}\left(\frac{d X_{t}^{E^{*}}}{d w_{t}^{E}}-1\right)^{2}<0
\end{aligned}
$$

The expected profit function is a concave function of exports, and the concavity of the profit function is determined entirely by the convexity of the external financing constraint $C(v)$ and the concavity of $F(x)$. Since we assume linear $F(x)$, the concavity of the profit function comes solely from the convexity of the external financing constraint.

In other words, the external financing constraint, $C(v)$, should be a convex function of the amount of the external funds, to guarantee that the profit function is concave. With a concave profit function, expected profits are raised if fluctuations in $w$ are reduced. The convexity of the external financing constraint provides a rationale for hedging against fluctuations in $w$.

\section{Shocks to the Firm's Cash Flows}

The domestic firm's ability to export in period $t$ depends on its ability to secure continual access to external funds. If the quantity of credit available to the domestic firm is decreased, while its foreign competitor still retains access to funds, the export profits of the domestic firm would decline.

The firm's cash flow is subject to many random shocks, including the exchange rate shock as well as shocks caused by shifts in domestic and foreign demand (booms and recessions), trade policy changes, productivity shocks, labor supply shocks, etc. We assume 
that cash flows are affected by two shocks: the aggregate shock, $\varepsilon_{t}$, and the shock, $u_{i t}$, specific to firm $i$. However, we assume that the firm can hedge against only the aggregate shock.

We model the exchange rate as a random walk process, i.e.

$$
e_{t}=e_{t-1} \varepsilon_{t}
$$

where the shock, $\varepsilon_{t}$, is serially uncorrelated and distributed normally with a mean of one and variance of $\sigma_{\varepsilon}^{2}$.

Thus, firm $i$ 's cash flow can be expressed as:

$$
w_{i t}^{E}=w_{i t-1}^{E}\left(1+\left(1-h_{i t}^{E}\right) \alpha_{i t}\left(\varepsilon_{t}-1\right)+u_{i t}\right)
$$

where $w_{i t-1}$ is the internal cash flow at the beginning of the period, $h_{i t}$ is the fraction of last period's cash flow that is hedged -hedge ratio- by firm $i$, and $u_{i t}$ is serially uncorrelated and distributed normally with a mean of zero and a variance of $\sigma_{u}{ }^{2} . \alpha_{i t}$ measures the expected correlation between the aggregate shock and cash flows during time $t$. We assume that the firm forms an expectation of this correlation at the beginning of the period $t$, and uses this expectation to decide on the optimal levels of exports and the hedge ratio.

The time line of the firm's decision to produce, and hedge within period $t$ is summarized below:

Period $t$ :

\begin{tabular}{lll}
\hline & & \\
Decision session & Production session & Profit realization session \\
The firm decides: & The firm produces/exports, Profit is realized: \\
$X_{i \mathrm{t}}{ }^{E}, h_{i t}{ }^{E}$ & and shocks are observed: & $e_{t}, w_{i t} \rightarrow \prod_{i t}^{E}$
\end{tabular}




$$
\text { given } e_{t-1}, w_{i t-1}, \alpha_{i t} \quad \varepsilon_{t}, u_{i t}
$$

Period $t$ is divided into three successive sessions: 1) decision, 2) production and 3) profit realization At the beginning of the period $t$, i.e. in the decision session, the firm has to decide how much it has to produce for exporting and how much to hedge. Each firm takes $\alpha_{i t}$ and the non-time varying parameters, $a, b$, and $\beta$ as given at the beginning of period $t$, when deciding $X_{i \mathrm{t}}{ }^{E}$, and $h_{i t}{ }^{E}$. In the production session, the firm produces good $X$ for exporting. During this session there will be shocks, but the effect of the shocks on the exchange rate and cash flows will be realized at the end of the period, or in the profit realization session.

When the firm completely hedges $(h=1)$, the firm's cash flow is immune to aggregate shocks, i.e. shocks to the exchange rate. Using (3), the external financing constraint, $C\left(v_{i t}{ }^{E}\right)$, is:

$$
C\left(v_{i t}^{E}\right)=\left[C_{i t}^{E} X_{i t}^{E}-w_{i t-1}^{E}\left(1+\left(1-h_{i t}^{E}\right) \alpha_{i t}\left(\varepsilon_{t}-1\right)+u_{i t}\right)\right]^{\beta}
$$

\section{The Firm's Decision of the Amount to Hedge}

We now model the hedging decision by the domestic firm. Assume that at the beginning of period $t$, the firm chooses $h_{i t}$ to maximize expected profits:

$$
\underset{h_{i t}^{E}}{\operatorname{Max}} E_{t}\left(\Pi\left(w_{i t}^{E}\right)\right)
$$

The first order condition for this problem is:

$$
E_{t}\left(\prod_{w} \frac{d w_{i t}}{d h_{i t}}\right)=w_{i t-1}^{E} \alpha_{i t} \operatorname{cov}\left(\Pi_{w}\left(\varepsilon_{i t}\right), \varepsilon_{i t}\right)
$$




$$
=w_{i t-1}^{E} \alpha_{i t} E_{t}\left[\Pi_{w w} \frac{d w_{i t}^{E}}{d \varepsilon_{t}}+\frac{\partial \Pi_{w}}{\partial \varepsilon_{t}}\right] \operatorname{cov}\left(w_{i t}^{E}, \varepsilon_{t}\right)=0
$$

Since $\operatorname{cov}\left(w_{i t}{ }^{E}, \varepsilon_{t}\right) \neq 0$, we get: ${ }^{9}$

$$
\begin{aligned}
& E_{t}\left[\Pi_{w w} \frac{d w_{i t}^{E}}{d \varepsilon_{t}}+\frac{\partial \Pi_{w}}{\partial \varepsilon_{t}}\right] \\
& =w_{i t-1}^{E}\left(1-h_{i t}^{E}\right) \alpha_{i t} E_{t}\left[\Pi_{w w}\right]+E_{t}\left[\frac{\partial}{\partial \varepsilon_{t}}\left\{e_{t} P_{t} \frac{d X_{i t}^{E}}{d w_{i t}^{E}}+e_{t} X_{i t}^{E} \frac{d P_{t}}{d X_{i t}^{E}} \frac{d X_{i t}^{E}}{d w_{i t}^{E}}-C_{t}^{E} \frac{d X_{i t}^{E}}{d w_{i t}^{E}}-\beta\left(C_{t}^{E} X_{i t}^{E}-w_{i t}^{E}\right)^{\beta-1}\left(C_{i t}^{E} \frac{d X_{i t}^{E}}{d w_{i t}^{E}}-1\right)\right\}\right] \\
& =w_{i t-1}^{E}\left(1-h_{i t}^{E}\right) \alpha_{i t} E_{t}\left[\Pi_{w w}\right]+e_{t-1} E_{t}\left[\frac{d X_{i t}^{E}}{d w_{i t}^{E}}\left(P_{t}+X_{i t}^{E} \frac{d P_{t}}{d X_{i t}^{E}}\right)\right]=0
\end{aligned}
$$

Thus, the optimal hedge ratio is:

$$
h_{i t}^{E^{*}}=1+\frac{e_{t-1} E_{t}\left[\frac{d X_{i t}^{E}}{d w_{i t}^{E}}\left(P_{t}^{*}+\frac{d P_{t}^{*}}{d X_{i t}^{E}} X_{i t}^{E}\right)\right]}{\alpha_{i t} w_{i t-1}^{E} E_{t}\left(\prod_{w w}\right)}
$$

From (21), the hedge ratio of the firm depends on its expected marginal revenue from additional export sales resulting from a currency depreciation as well as the expected correlation between the aggregate shock and cash flows, $\alpha_{i t}$. When the expected marginal revenue is zero, then $h_{i t}{ }^{E}=1$ is the optimum. In general, however, when exchange rates affect the marginal revenue of additional export sales, or export opportunities, the optimal hedging ratio is different from unity. Since $E_{t}\left[\prod_{w w}\right]$ is negative, whether $h^{*}<1$ or $h^{*} \geq 1$ depends on the sign of $\alpha_{i t}$.

\footnotetext{
${ }^{9}$ If $x$ and $y$ are normally distributed and $g(y)$ is nay at least once differential function of $y, \operatorname{cov}(x, g(y))=$ $E\left[g^{\prime \prime}(y)\right] \operatorname{cov}(x, y)$. See Rubinstein (1976) for proof.
} 
If $\alpha_{i t}$ is positive, the depreciation of the domestic currency will increase cash flows. In this case, from (21), the firm would choose to hedge less than completely. Since cash flows will tend to be high when exchange rates depreciate, the firm without hedging can take better advantage of the favorable export opportunities. In fact, depending on the parameters of (21), the firm may choose not to hedge at all $\left(h_{i t}{ }^{E^{*}}=0\right)$, to take maximum advantage of the currency depreciation.

Suppose instead that $\alpha_{i t}<0$. The shock affects the exchange rate and cash flows in opposite directions. Since its internal cash flows are low when the currency is depreciated and export opportunities are greater, the firm would benefit by obtaining a hedging contract that reduces the negative shock on its cash flow. Thus, hedging is likely to be complete $\left(h_{i t}^{E^{*}}=1\right)$ or the firm might even over hedge $\left(h_{i t}^{E^{*}}>1\right)$ by entering into contracts that pay greater, when cash flow hit by an adverse aggregate shock.

\section{The Aggregate Shock and Export Quantities}

Now consider the impact of the aggregate or the exchange rate shock on the export quantity of the domestic firm. As a benchmark, if we assume that the external financing

constraint, given by $C\left(v_{i t}{ }^{E}\right)$, is fixed, then the depreciation of the domestic currency results in more export sales. Domestic production costs become cheaper compared to costs of the foreign firm, and the domestic firm can grab more market share from the foreign firm.

Thus, from equation (11), the impact of changes in the exchange rate on the export quantity of the domestic firm is:

$$
\frac{d X_{i t}^{E^{*}}}{d \varepsilon_{t}}=\frac{2}{3 b} \frac{C_{i t}^{E}}{e_{t-1} E \varepsilon_{t}^{2}}=\frac{2}{3 b} \frac{C_{i t}^{E}}{e_{t-1}\left(\sigma^{2}+1\right)}>0
$$


If $C\left(v_{i t}^{E}\right)$ is not exogenously fixed, then the impact of the shock on the export quantity of the domestic firm depends on how the cash flow affects the external financing constraint:

$$
\frac{d X_{i t}^{E^{*}}}{d \varepsilon_{t}}=\frac{\frac{2}{3 b}\left[\frac{C_{i t}^{E}}{e_{t-1}\left(\sigma^{2}+1\right)}+2 \alpha_{i t} w_{i t-1}^{E}\left(1-h_{i t}^{E^{*}}\right) \frac{C_{i t}^{E}}{e_{t-1}}+2\left(C_{i t}^{E} X_{i t}^{E^{*}}-w_{i t}^{E}\right) \frac{C_{i t}^{E}}{e_{t-1}\left(\sigma^{2}+1\right)}\right]}{1+\frac{4}{3 b} \frac{C_{i t}^{E^{2}}}{e_{t-1}}} .
$$

The first term of the numerator in equation (24) gives the export quantity effect through the usual cost channel in equation (23). The rest captures the effect of the aggregate shock on the external financing constraint.

The impact of the aggregate shock on the export quantity again depends on $\alpha_{i t}$. Suppose that $\alpha_{i t}>0$, meaning that increased cash flows are correlated with a currency depreciation. The increased cash flows will allow the firm to produce and export more. Thus, under $\alpha_{i t}>$ 0 , the impact of the exchange rate on exports will tend to be large. Suppose instead that $\alpha_{i t}$ $<0$. Although the currency may depreciate, with decreased cash flows, the firm cannot take advantage of the favorable export opportunities. Thus, under $\alpha_{i t}<0$, the impact of the exchange rate on exports, with the financing constraint, will tend to be small. A key prediction of our model is that industries with $\alpha_{i t}>0$ will tend to have a larger impact of the exchange rate on exports than industries with $\alpha_{i t}<0$, other parameters suitably held constant.

Finally, by mitigating the effect of the financing constraints, hedging lowers the variability of the exchange rate impact on export production. From equation (21), we know that when $\alpha_{i t}>0$, the firm will choose $h_{i t}^{E^{*}}<1$, or even $h_{i t}^{E^{*}}=0$. When $\alpha_{i t}<0$, the firm will choose $h_{i t}^{E^{*}} \geq 1$. When $\alpha_{i t}>0$, hedging dampens the effect of exchange rates on 
exports. The cost channel of exchange rates on exports in equation (23) is in the same direction as the effect of financing constraints on exports in equation (24), so by mitigating the effects of the financing constraints, hedging dampens the effect of exchange rates on exports. When $\alpha_{i t}<0$, hedging amplifies the effect of exchange rates on exports. In this case, the cost channel in equation (23) is in the opposite direction of the financing constraint channel. By mitigating the effects of financing constraints, hedging enlarges the effect of exchange rates on exports. Thus, in both cases, hedging helps to offset the effects of the financing constraints, thereby decreasing the magnitude of the impact of the exchange rate on exports.

These effects of hedging on export production are depicted in Figures 1 and 2. Figure 1 depicts the relationship between the exchange rate, and cash flow, when $\alpha_{i t}>0$. As the exchange rate depreciates, cash flow and export production increases. This positive link between the exchange rate and export production is removed when the firm hedges completely. Figure 2 depicts the negative relationship between the depreciated exchange rate and export production, when $\alpha_{i t}<0$. If the firm hedges completely, there are no fluctuations in cash flow, and the firm can produce more for export.

In sum, the impact of the volatility of exchange rates on exports typically depends on the sign and the magnitude of $\alpha_{i t}$. We have shown that the impact of the exchange rate on exports will tend to vary positively with $\alpha_{i t}$. By mitigating the effect of the financing constraints, hedging will lower the variability of the exchange rate impact on export production. 


\section{Estimation Specification and Description of the Data}

\section{Intertemporal Considerations}

As developed, our model of exports and hedging is static. In the estimation, we fit our model on panel data of Japanese firms. Our model can be extended to an intertemporal framework since we are assuming that domestic firm $i$ chooses export quantities, $X_{i t}^{E}$ and the optimal hedging ratio, $h_{i t}^{E^{*}}$, at time $t$, based on $\alpha_{i t}$, and other fixed parameters of the model. As time evolves, the parameter $\alpha_{i t}$ changes, based on new information regarding the correlation between firm level cash flows and nominal exchange rates. We assume other parameters in the model as fixed over time.

\section{Specification of Estimation Equations}

We jointly estimate equations for export quantity, and foreign demand, using firm level panel data for Japanese multinationals. Rearranging (11), we obtain the estimation equation for the export quantity:

$$
X_{i t}^{E}=\left(1+\frac{4}{3 b} \frac{C_{i t}^{E^{2}}}{e_{t}}\right)^{-1}\left[\frac{a}{3 b}+\frac{C_{i t}^{F}}{3 b}-\frac{2}{3 b} \frac{C_{i t}^{E}}{e_{t}}+\frac{4}{3 b} \frac{C_{i t}^{E}}{e_{t}} w_{i t}^{E}\right]
$$

where we have assumed that the financing constraint is quadratic, i.e. $\beta=2$, and $a$ and $b$ are parameters to be estimated. ${ }^{10}$

\footnotetext{
${ }^{10}$ Preliminary estimates of $\beta$ showed that $\beta$ is statistically indistinguishable from 2 .
} 
Our second equation is foreign demand for Japanese exports -from equation (9):

$$
P_{t}=\frac{1}{2}\left(a-b X_{i t}^{E}+C_{i t}^{F}\right)+\mu_{i t}
$$

where $\mu_{i t}$ is approximation error, assumed to be serially uncorrelated and normally distributed with a mean of zero and a variance of $\sigma_{\mu}^{2}$.

Finally, we impose the financing constraint (27) - modified from equation (15) - on $(25) .^{11}$

$$
w_{i t}^{E}=w_{i t-1}^{E}\left[1+\tilde{\alpha}_{i t}\left(\varepsilon_{t}-1\right)+u_{i t}\right]
$$

where $u_{i t}$ is the firm specific shock, as defined in (15).

$\tilde{\alpha}_{i t}$ is defined as:

$$
\begin{aligned}
\tilde{\alpha}_{i t} & =\frac{\operatorname{cov}\left(\frac{w_{i t}-w_{i t-1}}{w_{i t-1}}, \frac{e_{t}-e_{t-1}}{e_{t-1}}\right)}{\operatorname{var}\left(\frac{e_{t}-e_{t-1}}{e_{t-1}}\right)} \\
& =\left(1-h_{i t}^{E^{*}}\right) \alpha_{i t}
\end{aligned}
$$

However, since $\tilde{\alpha}_{i t}$ is not known to the firm at the beginning of time $t$, we assume that the firm uses $\tilde{\alpha}_{i t-1}$, or the correlation between cash flows and exchange rates up to the period $t$, in predicting the time $t$ correlation. $\tilde{\alpha}_{i t}$ can be calculated from available data on exchange rates and firm level cash flows. ${ }^{12}$ Note, however, that in the absence of

\footnotetext{
${ }^{11}$ In our estimation, we substitute (27) into (25), and estimate (25) and (26) jointly.

${ }^{12}$ In our model specification, we could have fixed $\alpha_{i t}$ over time, so that $\alpha_{i t}=\alpha_{i}$ and simply estimated $\alpha_{i}$, along with the other parameters of the model. This estimation strategy is problematic for two reasons. First, the restriction violates the data since $\tilde{\alpha}_{i t}$ varies dramatically over time. Not all of this variation can be attributed to $h_{i t}{ }^{E^{*}}$, so $\alpha_{i t}$ must be varying over time. Second, since we do not have comprehensive data on $h_{i t}{ }^{E^{*}}, \alpha_{i t}$ cannot be separately estimated from $h_{i t}{ }^{*}$.
} 
comprehensive hedging data, which our and most other datasets lack, is difficult to disentangle the effect of hedging on cash flow.

Equations (25), and (26) with financing constraints (27) imposed can be jointly estimated consistently by nonlinear least squares (Amemiya, 1985) ${ }^{13}$. In particular, note that from equation (21), $h_{i t}{ }^{E^{*}}$ depends on the expectation $E\left(X_{i t}{ }^{E}\right)$ and not on the realization of $X_{i t}^{E}$. Thus $h_{i t}^{E^{*}}$ is not affected by the realization of $u_{i t}$ under our distributional assumptions regarding $u_{i t}$, and $\mu_{i t}$. Note that since all explanatory variables are exogenous to the firm specific shock $u_{i t}$, instrument variable estimation is unnecessary. Finally, we use the estimated parameters, $a$ and $b$ to calculate the elasticities of interest.

\section{Description of the data}

We estimate equations (25), and (26) with financing constraints (27) simultaneously for Japanese four digit export industries using firm level panel data. Since we are interested only in exporting firms, we include in our sample of industries, only industries with export sales to total sales of over 15 percent. In terms of value, exports from these 14 industries comprise over 90 percent of total Japanese manufacturing exports. We use data for the years 1982-1997. The firm level panel data are from the Japan Development Bank (JDB) Corporate database.

As an exchange rate measure, we use the trade weighted nominal exchange rate, i.e. we compute the trade weighted nominal exchange rates of the top 15 Japanese trading countries by their trade weights. Besides these 15 countries, less than 5 percent of Japan's

\footnotetext{
${ }^{13}$ We assume that $u_{i t}$ and $v_{i t}$ have a jointly normal, finite variance-covariance matrix. The efficiency of the estimation could be improved if $\tilde{\alpha}_{i t}$ can be estimated in one step with (25) and (26). However, the nonlinearity of (25) and (26) made this time-varying joint estimation different.
} 
trade is with other countries. The annual nominal exchange rates are from the International Financial Statistics (IFS); trade weights are fixed (1990) and are computed from the Japan Statistical Yearbook.

For industry specific marginal costs $\left(C_{E}\right)$, we use industry specific domestic wholesale price indices - from the Nikkei Economic Electronic Databank System (NEEDS). That is, we assume that domestic wholesale price indices represent a constant markup from domestic marginal costs, $C_{i t}^{E}=k_{E} P_{t}^{d}$.

We lack any direct information on foreign marginal costs. Thus, following Bodnar, Dumas, and Marston (1998), we simply assume that foreign wholesale price indices represent a constant markup from foreign marginal costs. That is, $C_{i t}{ }^{F}=k_{F} P_{t}^{f}$. We construct the aggregate foreign wholesale price index from industrial wholesale price indices of Japan's top 15 trading partners by using the same trade weights as above. The industrial wholesale price indices are from IFS.

For industry specific Japanese export prices $\left(P_{t}\right)$, we use industry specific export price indices - foreign currency bases- from the Bank of Japan (BOJ) Economic and Financial database. We assume that these prices are identical to the industry specific prices that appear in foreign demand.

Export quantities $\left(X_{i t}{ }^{E}\right)$ and cash flows $\left(w_{i t}{ }^{E}\right)$ are from the Japan Development Bank (JDB) database. Export quantities are defined as export values divided by the export price deflator for the industry. ${ }^{14}$ The firm's internal cash flow is defined as earnings before interest and taxes plus depreciation minus capital expenditures.

\footnotetext{
${ }^{14}$ It is well known that export price indices are poor measures for firm-level prices, which may introduce measurement error into export quantities. However, since export quantities in our estimation model is an independent variable, measurement error, while raising the standard error of the equation, will not bias the coefficient estimates.
} 
The post-hedging correlations between changes in the firm's cash flows and nominal exchange rates, $\tilde{\alpha}_{i t-1}$, are calculated for each year and each firm, using our exchange rate measure and firm level cash flows calculated from the JDB database. For $\tilde{\alpha}_{i 1982}$ in the first year of our working sample, 1982, we take the time series correlation -relative to the exchange rate variance- between changes in exchange rates and cash flows between 1975 and 1981. Thereafter, from 1983-1997, we update $\tilde{\alpha}_{i t-1}$ by taking the correlation between changes in exchange rates and cash flows up to the sample year. 


\section{Estimation Results}

\section{Descriptive Statistics}

There is large variation in average export quantities across Japanese industries.

Between 1982 and 1997, the average firm in the automobile industry had the largest export quantities, followed by the ordinary steel industry and the boiler and turbine industry

(Table 1). Internal cash flows were largest for the typical firm in the ordinary steel industry, followed by the automobile industry. The ratios of export sales to total sales averaged about 33 percent in our sample, with the musical instrument industry exporting about 70 percent of its output.

A peculiar institutional feature of Japanese industries is the keiretsu system. Table 1 shows that 100 percent of firms in the ordinary steel industry belong to the keiretsu, while none of the firms in the agricultural machinery and watch industries belong to the keiretsu. Keiretsu firms have close relations with banks. Hoshi, Kashyap, and Scharfstein (1991) argue and present empirical evidence showing that these close banking relationships mitigate the impact of financing constraints on corporate investment. He and $\mathrm{Ng}$ (1998) apply the Hoshi, Kashyap, and Scharfstein insight to corporate profit exposure to exchange rate fluctuations, and find that the profits of keiretsu firms are less exposed to exchange rate fluctuations, presumably because their banks extend loans to smooth out profit fluctuations.

Our model predicts that keiretsu firms should hedge less, since the se firms are less concerned with shocks to internal cash flows. The effect of keiretsu affiliation on the 
responsiveness of exports to exchange rate fluctuations is similar to the effect of hedging on exports; the exports of keiretsu firms should be less responsive to exchange rate fluctuations.

Finally, Table 1 depicts the ratio of firms that engaged in forward foreign currency sales/purchases in 1997, the indicator of financial hedging available in our $J D B$ database. While no firms in the specialty steel, measuring equipment, and watch industries engaged in forward foreign currency sales/purchases, the majority of firms in the boiler and turbine, construction machinery and optical instrument industries traded in these instruments.

We first examine the post-hedging correlation between changes in internal cash flows and changes in exchange rates, that is, $\tilde{\alpha}_{i t}$ defined in equation (28). Assume, for now, that 0 $<h_{i t}^{E}<1$. In this case, $\tilde{\alpha}_{i t}$ will have the same sign as $\alpha_{i t}$. There is heterogeneity in the sign of average $\tilde{\alpha}_{i t}$ across industries (Table 2). In specialty steel, for example, exchange rates and cash flows are negatively correlated, while in ordinary steel, they are positively correlated. Out of 14 industries, 10 industries have exchange rates and cash flows that are on average across firms and over time, positively correlated. Moreover, even within industries, there is substantial heterogeneity in $\tilde{\alpha}_{i t}$. Because of the heterogeneity, we present values for the firm with the highest average $\tilde{\alpha}_{i t}$ and the lowest average $\tilde{\alpha}_{i t}$ over the sample. For example, within the nine firms in the optical instrument industry, $\tilde{\alpha}_{i t}$ ranges 33 to -4. Apparently aggregate shocks - trade, productivity, fiscal, monetary, commodity price, and other shocks - affect the cash flows of different industries and firms in surprisingly different directions. 


\section{Estimation Results}

The estimation results of the equations of the supply of exports (25) and foreign demand (26) with financing constraints (27) are depicted in Table 3. In general, the results are remarkably good. Almost all the coefficients have the correct signs and are statistically significant. Foreign demand is correctly estimated as downward sloping $(b>0)$. Consistent with our priors, the estimate of the parameter $b$ tends to be higher in standardized products, like ordinary steel and metal machinery than in differentiated products, like automobiles. A rise in foreign costs raises export quantities $\left(k_{F}>0\right)$; while a rise in domestic costs lowers export quantities $\left(k_{E}>0\right)$, thus supporting the Cournot competition model adopted here. ${ }^{15}$ The goodness of fit statistic (R-squared) for the export equation ranges up to 0.88 , which is high for panel data.

To better examine if our model of financing constraints is valid, we estimated a model without financing constraints, i.e. equation (23). ${ }^{16}$ Generally, the estimation was unsuccessful. We achieved convergence in only one of the 14 industries estimated, implying that the specification without financing constraints fails to fit the data.

Elasticities of exports with respect to exchange rates can be calculated from the estimated parameters and average values of the data. The average elasticities range from 0.02 for the auto industry to 2.9 for the boiler and turbine industry, with large heterogeneity

\footnotetext{
15 The markup in domestic prices is equal to $\frac{1-k_{E}}{k_{E}}$. As seen from our estimation of $k_{E}$ in Table 3 , five out of fourteen industries have negative markups. Negative markups in domestic prices are not inconsistent with our model. In fact, Japanese firms in these industries may be incurring a loss in domestic markets, to be made up in profits in foreign markets.

${ }^{16}$ Results are not shown, to save space.
} 
within industries ${ }^{17}$ (Table 4). Given the heterogeneity, one or two firm outliers can distort the average elasticities. To reduce the problem of outliers, we also examine the export elasticity for the median firm in each industry.

In general, our average and median export elasticities are larger than what has been reported in the earlier literature (Table 4). The earlier literature used mostly aggregate data for a single country or aggregate data over a cross-section of countries. Most of the literature has examined the impact of exchange rate volatility on export quantities. ${ }^{18}$ In a study that reports the export elasticity of exchange rates, Thursby and Thursby (1987) report that the elasticity of exchange rates ranges from 0.129 to 4.87 . Hooper, Johnson and Marquez (2000) estimate short-run aggregate export elasticities for the OECD countries. They find elasticities are uniformly small, and generally statistically insignificant from zero.

One explanation for the small estimated export elasticities in the earlier work is that exporters are keeping foreign prices constant, or that prices are sticky in the buyer's currency (Knetter, 1992; Engel, 2002). For example, when the yen appreciates, because of sticky prices in dollars, the prices of Japanese exports in the U.S. market do not change. Since the relative prices of Japanese and U.S. goods in the U.S. market do not change, U.S. demand does not switch from Japanese to U.S. goods, keeping Japanese export quantities stable.

\footnotetext{
${ }^{17}$ Although the parameters are the same for each firm in the industry, the export elasticities are heterogeneous, because each firm has different export quantities, costs, and sensitivities of cash flows to exchange rate fluctuations.

${ }^{18}$ That is, the studies have examined the elasticity of exports with respect to exchange rate volatility, $V_{t}=\left[\frac{1}{m} \sum_{i=1}^{m}\left(\log e_{t+i-1}-\log e_{t+i-2}\right)^{2}\right]^{1 / 2}$. Chowdhury (1993) reports that the export elasticity of exchange rate volatility ranges from a low of 0.77 in Italy to a high of 0.82 in Japan. Arize (1996) reports the elasticity of exchange rate volatility of 0.128 using Korean data for the period 1971-1991. Parsley and Wei (1993), and Frenkel and Wei (1994) among others find that volatility has no effect on trade. See the references in Wei (1999).
} 
From our parameter estimates, we can calculate the elasticity of export prices to exchange rate changes, using the equation (9). The calculated elasticities are generally very small. ${ }^{19}$ The average elasticities range from 0 for the auto industry to 0.01 for the musical instrument industry. Thus, when the yen depreciates, export prices decline, but the percentage changes in export prices are typically much smaller than the yen depreciation.

Thus, the potential flexibility of prices in the buyer's currency cannot explain our finding of sizeable export elasticities. Rather, we attribute our sizeable export elasticities to changes in financing constraints that are correlated with exchange rate fluctuations. For example, in 10 out of 14 industries, an exchange rate depreciation is on average positively related to a relaxation of financing constraints. In these industries, the relaxation of financing constraints will mean that firms can produce more for export, when their exchange rate is depreciated. In the remaining industries, an exchange rate depreciation is related to tightening financing constraints. However, as explained below, firms in these industries appear to be hedging extensively, to mitigate or even offset, the negative effect of aggregate shocks on cash flow.

\section{Effects of Financing Constraints, and Hedging on Export Elasticities}

When $\tilde{\alpha}_{i t}>0$, an exchange rate depreciation is correlated with a loosened financing constraint, implying an expansion in exports. When $\tilde{\alpha}_{i t}<0$, financing constraints tighten

\footnotetext{
${ }^{19}$ Changes in export prices are small, because of the small estimated demand parameter, 'b' in equation (26).
} 
when the exchange rate depreciates, constraining exports. However, hedging activity will be able to offset the effect of tightening financing constraints.

Thus, our model predicts that firms with positive and high $\tilde{\alpha}_{i t}$ should have higher export elasticities than firms with negative $\tilde{\alpha}_{i t}{ }^{20}$ Figure 3 depicts the cross-firm association between $\tilde{\alpha}_{i t}$ and the export elasticities. As predicted by the model, the variables have a positive relationship. The regression coefficient of 0.27 is statistically significant at the 5 percent level.

Another implication of our model is that firms that are less financially constrained should have lower exchange rate elasticities (when $\alpha_{i t}>0$ ). Thus, compared to the exports of non-keiretsu firms, the exports of keiretsu firms who are presumably less financially constrained, should have lower exchange rate elasticities. Of the 11 industries with both keiretsu and non-keiretsu firms, 7 industries have lower exchange rate elasticities -both average and median- for keiretsu firms (Table 5).

As a further test, we interact a dummy that takes on a value of one when the firm belongs to a keiretsu -the keiretsu dummy- with the financing constraint, (27), and reestimated (25) and (26), along with this additional constraint. If keiretsu affiliation helps in lessening financing constraints, the coefficient on this interaction term should be negative. Of the 11 industries with both keiretsu and non-keiretsu firms, 5 industries have significantly negative coefficients on the interaction term (Table 5). In no industry was the interaction coefficient significantly positive.

As to the effect of hedging on export elasticities, our theory predicts that hedging firms

\footnotetext{
${ }^{20}$ Again, for now, assume that hedging cannot fully offset the impact of the financing constraints. Thus, $\tilde{\alpha}_{i t}$ has the same sign as $\alpha_{i t}$.
} 
will have lower export elasticities. Of the industries with both hedging and non-hedging firms, we find that hedging firms typically have lower export elasticities, thus supporting our model (Table 5). Surprisingly we find that keiretsu firms are more likely to hedge than non-keiretsu firms. However, as mentioned, forward foreign currency sales/purchases are a very incomplete measure of firm overall hedging activities, and our negative result may be more of an indication of incomplete data coverage, than a failure of our model.

Given the inadequate data on overall hedging activities, we compare the actual export elasticities with the hypothetical elasticities under the assumption that the firm hedges completely $\left(h_{i t}=1\right)$. We set $h_{i t}=1$ in equation (24), and compare the export elasticities thus obtained (Table 6) with the actual export elasticities (Table 4). By this methodology, we can capture the extent of actual hedging, not only through financial means, but also through operational means such as foreign direct investment. In most industries, the elasticities under complete hedging are much lower than the actual elasticities. In only two industries -specially steel and ordinary steel- do firms appear to be hedging fully. In other industries, firms are either significantly under-hedging $\left(h_{i t}<1\right.$, if $\left.\alpha_{i t}>0\right)$ or over-hedging $\left(h_{i t}>1\right.$, if $\left.\alpha_{i t}<0\right)$-which is consistent with what equation (21) in our model predicts. 


\section{Conclusion}

In this paper, we developed a model of an exporting firm that experiences fluctuating exchange rates and shocks to its cash flow. The firm uses its cash flow and borrows from the financial markets to produce for export later in the period. The exchange rate and shocks to cash flows are correlated, but the correlation could be positive or negative. If, for

example, they are negatively correlated, then the firm will suffer from low cash flows when its exchange rate is depreciated. That is, the firm's production will be constrained exactly at the time when its export opportunities are greatest. This provides the rationale for the firm to hedge against shocks to its cash flow.

We test and apply the model to firm level data on Japanese exporters. We estimate the model on 14 separate Japanese industries, and find that the model fits the data remarkably well for most industries. Our sample of 14 industries covers 90 percent of Japanese manufacturing export in terms of value, thus our sample is almost representative of the entire Japanese manufacturing export sector.

We show that financing constraints influence hedging decisions, and the sensitivity of export volumes to exchange rate fluctuations. Our model that explicitly includes financing constraints fits the data much better than an alternative model that excludes financing constraints. Firms that are less financially constrained -that its, keiretsu firms- tend to have lower elasticities of export with respect to exchange rates than non-keiretsu firms, which is consistent with the existence of financial constraints.

An important contribution of our paper is the calculation of the elasticity of exports with respect to changes in exchange rates, using firm level data. Most previous work have used 
data for a single country or a cross-section of countries to calculate such elasticities (See Hooper, Johnson, and Marquez, 2000). We find that average elasticities of exports with respect to exchange rates are quite high, ranging from 0.01 for the auto industry to as much as 2.9 for the boiler and turbine industry. In most industries, our calculated elasticities are generally higher than what have been found in previous work, using more aggregated data. Thus, our work casts some doubt on the prevailing wisdom -based on results from more aggregated data - that exchange rates have little effect on trade (Hooper, Johnson, and Marquez, 2000).

More broadly, an important puzzle in international macroeconomics is the exchange rate disconnect puzzle (Obstfeld and Rogoff, 2000). Based partly on the empirical findings of Baxter and Stockman (1989), Flood and Rose (1995) and others, nominal exchange rates seem to be disconnected from other macroeconomic variables, including export volumes. This paper relates nominal exchange rates to export volumes at the firm level and finds that export volumes are strongly affected by changes in exchange rates.

As in earlier work (see Engel, 2002 for a review), we too find that prices are sticky in the buyer's currency. In our model of exports, the strong response of export volumes to exchange rate fluctuations arises not because of changes in the buyer's currency prices, but because of a loosening of financing constraints, either through the direct beneficial effect of exchange rate shocks on cash flows, or through hedging activities.

It may be interesting to estimate the response of exports to exchange rates changes at the firm level, using the data of other countries. Japan, admittedly, may be an outlier. In the ir comparison of average export growth, before and after 1973, when the fixed exchange rate regime changed to a floating exchange rate regime, Baxter and Stockman (1989, Table 8), find that out of 49 countries, only Japan had export growth rates higher in the post 1973 
period. However, recent work by Gourinchas (1999) for France and by Goldberg and Tracy (1999) for the U.S. find that exchange rate fluctuations do impact real quantities -labor demand- at the disaggregate level. 


\section{References}

1. Allayannis, G., and A. Mozumdar, 1999, "Cash Flow, Investment, and Hedging", mimeo.

2. Allayannis, G., and E. Ofek, 2001, "Exchange Rate Hedging: Financial versus Operational Strategies", American Economic Review, vol. 91 No.2, 391-395.

3. Amemiya, T., 1977, "The Maximum likelihood and the Nonlinear Three-Stage Least Squares Estimator in the General Nonlinear Simultaneous Equation Model”, Econometrica 45, 955-968.

4. Aguiar, M., 2001, "Devaluation, Foreign Currency Exposure and Investment: The Case of Mexico". University of Chicago, Mimeo.

5. Arize, A. C., 1996, "The Impact of Exchange rate Uncertainty on Export Growth: Evidence from Korean Data", International Economic Journal 10, 49-60.

6. Baba, N., and K. Fukao, 2000, "Currency Risk Exposure of Japanese Firms with Overseas Production Bases: Theory and Evidence”, Institute for Monetary and Economic Studies, Bank of Japan, Discussion Paper No. 2000-E-1.

7. Bartov, E., and G. M. Bodnar, 1994, "Firm Valuation, Earnings Expectations and the Exchange Rate Exposure Effect", Journal of Finance 49, 1755-1785.

8. Baxter M., and A. C. Stockman, 1989, "Business Cycle and the Exchange Rate Regime: Some International Evidence", Journal of Monetary Economics 23, 377 400.

9. Bernard, A., and J.B. Jensen, 2001, "Why Some Firms Export", Working Paper, Dartmouth College.

10. Bernard, A., J. Eaton, J.B. Jenson, and S. Kortum, 1999, "Plants and Productivity in Investment Trade: A Ricardian Reconciliation", Working Paper, Boston University.

11. Bresnahan, T. F., 1989, "Empirical Studies of Industry with Market Power", Handbook of Industrial Organization, Volume II, 1.12-1055.

12. Betts, C., and M.B. Devereux, 2000, "The exchange Rate Dynamics in a Model of Pricing-to-Market", The Journal of International Economics 50, 215-244. 
13. Chowdhury, A.R., 1993, "Does Exchange Rate Volatility Depress Trade Flows? Evidence from Error Correction Models”, The Review of Economics and Statistics, 75, 700-706.

14. Cushman, D.O., 1983, “ The Effects of Real Exchange Rate Risk on International Trade", Journal of International Economics 15, 45-63.

15. Das, S., Roberts, M., and J. Tybout, 2001, "Market Entry costs, Producer Heterogeneity, and Export Dynamics", Manuscript, Pennsylvania State University.

16. Dekle, R., 2001, "Exchange Rates and Corporate Exposure: Evidence from Japanese Firm Level Data", mimeo.

17. Dominguez, K. M. E. and L.L. Tesar, 2001, "Exchange Rate Exposure”, mimeo.

18. Dominguez, K. M. E., and L. L. Tesar, 2001, “A Re-Examination of Exchange Rate Exposure", NBER working paper 8128.

19. Engel C., 2002, "Expenditure Switching and Exchange Policy", NBER Working Paper No. 9016.

20. Forbes, K., 2002, "How Do Large Depreciations Affect Firm Performance", NBER Working Paper No. 9095.

21. Flood, R. P., and A. K. Rose, 1995, "Fixing Exchange Rates: A Virtual Quest for Fundamentals”, NBER Working Paper No. 4503.

22. Frankel, J., 1984, The Yen-Dollar agreement: Liberalizing Japanese Capital Markets, Institute of International Economics, Washington, D.C.

23. Frankel, J., and S. Wei, 1994, "Trade Blocs and Currency Blocs", NBER Working Paper No. 4335.

24. Froot, K., D. Scharfstein, and J. Stein, 1993, "Risk Management: Coordinating Corporate Investment and Financing Policies", Journal of Finance 48, 1624-1658.

25. Goldberg, L., and J. Tracy, 1999, "Exchange Rates and Local Labor Markets", NBER Working Paper No. 6985.

26. Goldberg, P. and M. Knetter, 1997, "Goods, Prices and Exchange Rates: What Have We Learned?" The Journal of Economic Literature, 35, 1243-1272

27. Goldstein, M. and M. S. Khan, 1985, "Income and Price Effects in Foreign Trade", Handbook of International Economics, vol. 2. R.W. Jones and P.B. Kenen, eds. Amsterdam: North-Holland. 
28. Gotur, P., 1985, "Effects of Exchange Rates Volatility on Trade: Some Further Evidence", International Monetary Staff Papers 32, 475-512.

29. Gourinchas, P., 1999, “Exchange Rates Do Matter: French Job Reallocation and Exchange Rate Turbulence, 1984-1992”, European Economic Review 43, 1279 1316.

30. He, J., and L. K. Ng, 1998, “The Foreign Exchange Exposure of Japanese Multinational Corporations", Journal of Finance 53, 733-753.

31. Hooper, P., K. Johnson, and J. Marquez, 2000, "Trade Elasticities for G-7 Countries", Princeton Studies in International Economics No. 87.

32. Hoshi, T., Kashyap, A., and D. Scharfstein, 1991, “Corporate structure, liquidity, and investment: Evidence from Japanese Industrial Groups, Quarterly Journal of Economics 106, 33-60.

33. Kenen, P. B., and D. Rodrik, 1986, "Measuring and Analyzing the Effects of shortTerm Volatility in Real Exchange Rates", The Review of Economics and Statistics 68, 311-315.

34. Knetter, M., 1992, "International Comparisons of Pricing-to-Market Behavior" American Economic Review 79, 198-210.

35. Mussa, M., 1986, "Nominal Exchange Rates Regimes and the Behavior of Real Exchange Rates: Evidence and Implications", Carnegie-Rochester Conference Series on Public Policy 25, 117-216.

36. Obstfeld, M., 2002, "Exchange Rates and Adjustment: Perspectives from the New Open Economy Macroeconomics", manuscript, University of California, Berkeley.

37. Orcutt, G. H., 1950, "Measurement of Price Elasticities in International Trade", The Review of Economics and Statistics 32, 117-132.

38. Parley, D., and S. Wei, 1993, "In significant and Inconsequential Hypotheses: The Case of U.S, Bilateral trade", Review of Economics and Statistics 4, 606-615.

39. Pozo, S., 1992, "Conditional Exchange Rate Volatility and the Volume of International Trade: Evidence from the Early 1900s", The Review of Economics and Statistics 74, 325-329.

40. Rubinstein, M., 1976, "The Valuation of Uncertain Income Streams and the Pricing of Options", Bell Journal of Economics 7, 407-426. 
41. Thursby J.G., and M.C. Thursby, 1987, "Bilateral Trade Flows, the Linder Hypothesis, and Exchange Risk", The Review of Economics and Statistics 69, 488495.

42. Wei, S., 1999, "Currency hedging and goods trade", European Economic Review 43. 1371-1394. 
Table 1 Descriptive Statistics ${ }^{1)}$

\begin{tabular}{|c|c|c|c|c|c|c|c|c|}
\hline \multirow[b]{2}{*}{ Industry } & \multicolumn{2}{|c|}{ Export Quantity ${ }^{2)}$} & \multicolumn{2}{|c|}{ Internal Cash Flows $^{3}$} & \multirow{2}{*}{$\begin{array}{l}\text { Number } \\
\text { of Firms }\end{array}$} & \multirow{2}{*}{$\begin{array}{c}\text { Average } \\
\text { Export } \\
\text { Ratios }\end{array}$} & \multirow{2}{*}{$\begin{array}{l}\text { Ratio of } \\
\text { Firms in } \\
\text { Keiretsu }\end{array}$} & \multirow{2}{*}{$\begin{array}{c}\text { Ratio of } \\
\text { firms } \\
\text { using } \\
\text { hedging }\end{array}$} \\
\hline & Average & S.D. ${ }^{5)}$ & Average & S.D. ${ }^{5)}$ & & & & \\
\hline Ordinary steel & 2193 & 1576 & 72.25 & 63.41 & 7 & 0.20 & 1.00 & 0.43 \\
\hline Specialty steel & 193 & 135 & 6.87 & 5.96 & 4 & 0.16 & 0.25 & 0.00 \\
\hline Boiler and turbine & 1596 & 1835 & 21.11 & 37.92 & 8 & 0.34 & 0.75 & 1.00 \\
\hline Metal machinery & 126 & 125 & 2.34 & 5.35 & 14 & 0.38 & 0.36 & 0.21 \\
\hline Textile machinery & 93 & 108 & 1.75 & 2.03 & 8 & 0.31 & 0.38 & 0.13 \\
\hline Agricultural machinery & 236 & 354 & 6.42 & 12.74 & 5 & 0.17 & 0.00 & 0.20 \\
\hline Construction machinery & 741 & 1008 & 9.07 & 13.88 & 4 & 0.22 & 0.50 & 0.75 \\
\hline Office machinery & 463 & 503 & 6.54 & 8.00 & 11 & 0.29 & 0.36 & 0.45 \\
\hline Communication equipment & 128 & 158 & 2.72 & 3.53 & 12 & 0.22 & 0.42 & 0.17 \\
\hline Musical instrument & 451 & 447 & 3.16 & 8.52 & 10 & 0.69 & 0.30 & 0.40 \\
\hline Autos & 7989 & 8107 & 52.53 & 107.96 & 9 & 0.35 & 0.67 & 0.11 \\
\hline Measuring equipment & 176 & 165 & 3.91 & 3.60 & 2 & 0.18 & 0.50 & 0.00 \\
\hline Optical instrument & 1099 & 2093 & 9.85 & 24.01 & 9 & 0.55 & 0.33 & 0.67 \\
\hline Watches & 638 & 507 & 4.85 & 5.05 & 2 & 0.59 & 0.00 & 0.00 \\
\hline All Industries & 1271 & 3375 & 14.95 & 43.96 & 105 & 0.33 & 0.42 & 0.32 \\
\hline
\end{tabular}

Note:

1) Averages, between 1982-1997 over all the firms in the industry.

2) Export Quantity=Export Value in Thousands of Yen / Export Price Index.

3) Millions of Yen.

4) Fraction of firms that engaged in forward exchange rate sales/and purchases in 1997.

5) Standard Deviation. 
Table 2 Statistical Association of Changes in Internal Cash Flows with Changes in Exchange Rates $\left(\tilde{\alpha}_{i t}\right)^{1)}$

\begin{tabular}{|l|c|c|c|c|}
\hline Industry & Average & Median $^{3)}$ & $\operatorname{Max}^{4)}$ & $\operatorname{Min}^{5)}$ \\
\hline Ordinary steel & 4.03 & 2.48 & 12.61 & 0.75 \\
Specialty steel & -8.91 & -1.43 & 1.58 & -34.38 \\
Boiler and turbine & -1.83 & -1.03 & 9.23 & -20.90 \\
Metal machinery & 2.05 & 2.15 & 25.97 & -16.07 \\
Textile machinery & 1.54 & 1.49 & 8.80 & -5.13 \\
Agricultural machinery & 0.30 & 0.48 & 3.57 & -3.35 \\
Construction machinery & -3.95 & -4.63 & 5.28 & -11.83 \\
Office machinery & 0.72 & 1.41 & 3.89 & -7.37 \\
Communication equipment & 2.13 & 0.66 & 9.60 & -1.33 \\
Musical instrument & 4.50 & 0.70 & 41.92 & -33.28 \\
Autos & 1.85 & 1.93 & 4.82 & -2.33 \\
Measuring equipment & 0.53 & 0.53 & 1.14 & -0.08 \\
Optical instrument & 5.54 & 3.34 & 32.51 & -4.43 \\
Watches & -0.21 & -0.21 & 0.58 & -1.00 \\
\hline
\end{tabular}

Note:

1) $\tilde{\alpha}_{i t}=\frac{\operatorname{cov}\left(\frac{w_{i t}}{w_{i t-1}}-1, \frac{e_{t}}{e_{t-1}}-1\right)}{\operatorname{var}\left(\frac{e_{t}}{e_{t-1}}-1\right)}$ for every $t, 1983-1997$

2) $\frac{1}{N} \frac{1}{14} \sum_{i}^{N} \sum_{t=198314 \times N}^{1997} \alpha_{i t}$, where $\mathrm{N}$ is the number of firms in the industry.

3) Median over all the firms in the industry.

4) $\tilde{\alpha}_{i t}$ for firm in the industry with the highest value of $\tilde{\alpha}_{i t}$.

5) $\tilde{\alpha}_{i t}$ for firm in the industry with the lowest value of $\tilde{\alpha}_{i t}$. 
Table 3 Estimation Results by Industry (across firms in the industry, annual data for 1982-97)

\begin{tabular}{|c|c|c|c|c|c|c|}
\hline \multirow[b]{2}{*}{ Industry } & \multicolumn{4}{|c|}{ Parameter Estimates } & \multicolumn{2}{|c|}{$\begin{array}{c}\text { Goodness of Fit } \\
\left(\mathrm{R}^{2}\right)\end{array}$} \\
\hline & $a$ & $b$ & $k_{F}$ & $k_{E}$ & Eq (25) & $\mathrm{Eq}(26)$ \\
\hline Ordinary steel & $\begin{array}{c}227.17^{* * *} \\
(34.35)\end{array}$ & $\begin{array}{l}0.38^{* *} \\
(2.27)\end{array}$ & $\begin{array}{l}0.31^{* * *} \\
(10.51)\end{array}$ & $\begin{array}{l}0.36^{* *} \\
(2.46)\end{array}$ & 0.32 & 0.49 \\
\hline Specialty steel & $\begin{array}{c}218.70^{* * *} \\
(43.41)\end{array}$ & $\begin{array}{c}0.06^{*} \\
(1.88)\end{array}$ & $\begin{array}{c}0.09^{* * *} \\
(4.03)\end{array}$ & $\begin{array}{l}2.45^{* *} \\
(2.13)\end{array}$ & 0.28 & 0.26 \\
\hline Boiler and Turbine & $\begin{array}{l}197.85^{* * *} \\
(251.68)\end{array}$ & $\begin{array}{c}0.08^{* * *} \\
(4.59)\end{array}$ & $\begin{array}{c}0.02^{* * *} \\
(5.37)\end{array}$ & $\begin{array}{c}0.86^{* * *} \\
(4.88)\end{array}$ & 0.75 & 0.10 \\
\hline Metal machinery & $\begin{array}{c}209.22^{* * *} \\
(194.75)\end{array}$ & $\begin{array}{c}2.77^{* * * *} \\
(8.61)\end{array}$ & $\begin{array}{l}-0.03^{* * *} \\
(-6.00)\end{array}$ & $\begin{array}{c}0.17^{* * * *} \\
(6.22)\end{array}$ & 0.03 & 0.04 \\
\hline Textile machinery & $\begin{array}{l}204.15^{* * *} \\
(113.30)\end{array}$ & $\begin{array}{c}0.10 \\
(1.46)\end{array}$ & $\begin{array}{c}0.06^{* * *} \\
(6.11)\end{array}$ & $\begin{array}{l}1.80^{\text {** }} \\
(2.27)\end{array}$ & $3.39^{\mathrm{E}-3}$ & 0.28 \\
\hline Agricultural machinery & $\begin{array}{c}225.62^{* * *} \\
(81.02)\end{array}$ & $\begin{array}{c}0.04^{* * *} \\
(3.70)\end{array}$ & $\begin{array}{c}0.05^{* * *} \\
(3.66)\end{array}$ & $\begin{array}{c}2.96^{* * *} \\
(4.02)\end{array}$ & 0.88 & 0.17 \\
\hline Construction machinery & $\begin{array}{c}197.28^{* * *} \\
(47.05)\end{array}$ & $\begin{array}{c}0.02 \\
(1.40)\end{array}$ & $\begin{array}{l}0.06^{* *} \\
(2.47)\end{array}$ & $\begin{array}{c}2.81 \\
(1.50)\end{array}$ & 0.74 & 0.11 \\
\hline Office machinery & $\begin{array}{c}207.67^{* * *} \\
(63.90)\end{array}$ & $\begin{array}{l}0.19^{* * *} \\
(2.68)\end{array}$ & $\begin{array}{l}0.31^{* * *} \\
(18.85)\end{array}$ & $\begin{array}{c}0.49^{* * *} \\
(3.95)\end{array}$ & 0.21 & 0.68 \\
\hline Communication equipment & $\begin{array}{l}155.74 \\
(1.38)\end{array}$ & $\begin{array}{c}1.20 \\
(0.99)\end{array}$ & $\begin{array}{c}1.89 \\
(1.56)\end{array}$ & $\begin{array}{l}0.37^{*} \\
(1.66)\end{array}$ & 0.04 & 0.03 \\
\hline Musical instrument & $\begin{array}{c}253.50^{* * *} \\
(43.50)\end{array}$ & $\begin{array}{l}0.78^{* * *} \\
(2.76)\end{array}$ & $\begin{array}{l}0.30^{* * *} \\
(10.70)\end{array}$ & $\begin{array}{l}0.22^{* * *} \\
(4.27)\end{array}$ & 0.08 & 0.48 \\
\hline Autos & $\begin{array}{c}215.34^{* * *} \\
(123.63)\end{array}$ & $\begin{array}{l}0.003 \\
(0.28)\end{array}$ & $\begin{array}{c}0.05^{* * * *} \\
(6.85)\end{array}$ & $\begin{array}{l}12.57 \\
(0.29)\end{array}$ & 0.49 & 0.26 \\
\hline Measuring equipment & $\begin{array}{c}206.95^{* * *} \\
(14.25)\end{array}$ & $\begin{array}{c}3.60^{* * * *} \\
(6.09)\end{array}$ & $\begin{array}{c}0.02 \\
(0.12)\end{array}$ & $\begin{array}{c}0.03 \\
(0.14)\end{array}$ & 0.59 & $4.17^{\mathrm{E}-6}$ \\
\hline Optical instrument & $\begin{array}{c}208.08^{* * *} \\
(109.09)\end{array}$ & $\begin{array}{c}0.03^{* * *} \\
(3.36)\end{array}$ & $\begin{array}{l}0.12^{* * *} \\
(12.12)\end{array}$ & $\begin{array}{l}1.36^{* * *} \\
(3.57)\end{array}$ & 0.82 & 0.52 \\
\hline Watches & $\begin{array}{c}226.91^{* * *} \\
(69.65)\end{array}$ & $\begin{array}{l}0.02^{*} \\
(1.73)\end{array}$ & $\begin{array}{c}0.07^{* * *} \\
(4.14)\end{array}$ & $\begin{array}{l}2.12^{* *} \\
(2.12)\end{array}$ & 0.52 & 0.39 \\
\hline
\end{tabular}

Note:

1) t-statistics in parenthesis.

2) $* * *, * *, *$ denote significance at the 1,5 and 10 percent levels, respectively

3) Estimation equations:

$$
\begin{aligned}
& X_{i t}^{E}=\left(1+k_{E}^{2} \frac{4}{3 b} \frac{P_{t}^{d^{2}}}{e_{t}}\right)^{-1}\left[\frac{a}{3 b}+k_{F} \frac{P_{t}^{f}}{3 b}-k_{E} \frac{2}{3 b} \frac{P_{t}^{d}}{e_{t}}+k_{E} \frac{4}{3 b} \frac{P_{t}^{d}}{e_{t}} w_{i t}^{E}\right] \\
& P_{t}=\frac{1}{2}\left(a_{1}-b X_{i t}^{E}+k_{F} P_{t}^{f}\right)+\mu_{i t} \\
& \text { where } w_{i t}^{E}=w_{i t-1}^{E}\left(1+\tilde{\alpha}_{i t}\left(\varepsilon_{t}-1\right)+u_{i t}\right)
\end{aligned}
$$


Table 4 Exchange Rate Elasticities of Exports and Export Prices (by Industry, in Percent)

\begin{tabular}{|l|c|c|c|c|c|}
\hline \multirow{2}{*}{ Industry } & \multicolumn{4}{|c|}{ Export Elasticity $^{1)}$} & ${\text { Price } \text { Elasticity }^{2)}}^{(3)}$ \\
\cline { 2 - 6 } & Average $^{3)}$ & Median $^{4)}$ & Max $^{5)}$ & Min $^{6}$ & Average \\
\hline Ordinary steel & 0.739 & 0.139 & 3.837 & 0.063 & -0.0047 \\
Specialty steel & 0.347 & 0.407 & 0.452 & 0.124 & -0.0001 \\
Boiler and turbine & 2.894 & 0.374 & 15.306 & 0.062 & -0.0013 \\
Tetal machinery & 1.695 & 1.508 & 7.330 & 0.201 & -0.0090 \\
Textile machinery & 1.754 & 1.096 & 5.608 & 0.308 & -0.0002 \\
Consicultural machinery & 2.283 & 1.828 & 5.480 & 0.063 & -0.0001 \\
Office machion machinery & 1.615 & 1.547 & 3.306 & 0.060 & -0.0001 \\
Communication equipment & 2.447 & 1.107 & 9.578 & 0.217 & -0.0022 \\
Musical instrument & 2.288 & 1.511 & 8.610 & 0.312 & -0.0047 \\
Autos & 1.964 & 1.860 & 5.015 & 0.364 & -0.0097 \\
Measuring equipment & 0.015 & 0.007 & 0.043 & 0.001 & 0.0000 \\
Optical instrument & 0.125 & 0.125 & 0.255 & -0.005 & -0.0002 \\
Watches & 2.120 & 1.594 & 6.256 & 0.072 & -0.0004 \\
\hline
\end{tabular}

Note:

1) $\frac{d X_{t}}{X_{t}} / \frac{d e_{t}}{e_{t}}$

2) $\frac{d P_{t}}{P_{t}} / \frac{d e_{t}}{e_{t}}$.

3) Average over all the firms in the industry.

4) Median over all the firms in the industry.

5) Firm with the highest elasticity.

6) Firm with the lowest elasticity. 
Table 5 Export Elasticities for Keiretsu and Non-Keiretsu Firms (by Industry, in Percent)

\begin{tabular}{|c|c|c|c|c|c|c|c|c|c|c|}
\hline \multirow[b]{2}{*}{ Industry } & \multicolumn{2}{|c|}{ Keiretsu Firms ${ }^{1), 3)}$} & \multicolumn{2}{|c|}{ Non-Keiretsu Firms ${ }^{1), 2), 4)}$} & \multicolumn{2}{|c|}{ Firms using hedging } & \multicolumn{2}{|c|}{ Firms w/o hedging } & \multirow{2}{*}{\multicolumn{2}{|c|}{$\begin{array}{c}\text { Coefficient on } \\
\left.\text { Keiretsu dummy } \times w_{i t}{ }^{E} 7\right)\end{array}$}} \\
\hline & Average & Median & Average & Median & Average & Median & Average & Median & & \\
\hline Ordinary steel & 0.32 & 0.06 & n.a. & n.a. & 0.05 & 0.06 & 0.52 & 0.30 & 0.11 & $(0.30)$ \\
\hline Specialty steel & 7.49 & 7.49 & 6.24 & 8.23 & n.a. & n.a. & 6.56 & 7.84 & -0.19 & $(-1.09)$ \\
\hline Boiler and turbine & 0.94 & 0.35 & 29.72 & 29.72 & 8.14 & 1.02 & n.a. & n.a. & -0.73 & $(-3.73)$ \\
\hline Metal machinery & 13.94 & 7.73 & 39.03 & 22.10 & 17.14 & 21.75 & 33.60 & 18.64 & 0.12 & $(0.21)$ \\
\hline Textile machinery & 4.66 & 5.34 & 14.83 & 7.91 & 5.34 & 5.34 & 11.82 & 7.86 & -0.58 & $(-3.63)$ \\
\hline Agricultural machinery & n.a. & n.a. & 25.98 & 12.57 & 0.39 & 0.39 & 32.38 & 17.81 & n.a. & n.a. \\
\hline Construction machinery & 2.22 & 2.22 & 2.78 & 2.78 & 1.61 & 0.40 & 5.16 & 5.16 & 0.61 & $(1.08)$ \\
\hline Office machinery & 2.84 & 1.10 & 1.57 & 0.39 & 0.33 & 0.23 & 3.44 & 1.65 & -0.87 & $(-5.09)$ \\
\hline Communication equipment & 2.29 & 2.14 & 2.82 & 1.64 & 1.24 & 1.24 & 2.87 & 2.14 & -0.85 & $(-2.05)$ \\
\hline Musical instrument & 0.77 & 0.54 & 2.24 & 1.64 & 2.47 & 0.72 & 1.35 & 1.61 & -0.73 & $(-5.29)$ \\
\hline Autos & 0.48 & 0.36 & 0.31 & 0.04 & 0.35 & 0.35 & 0.49 & 0.23 & 0.74 & $(2.91)$ \\
\hline Measuring equipment & 35.33 & 35.33 & 669.92 & 669.92 & n.a. & n.a. & 352.62 & 352.62 & 1.92 & $(0.27)$ \\
\hline Optical instrument & 12.29 & 10.17 & 39.65 & 5.27 & 6.95 & 2.01 & 77.69 & 12.94 & 0.45 & $(1.11)$ \\
\hline Watches & n.a. & n.a. & 63.74 & 63.74 & n.a. & n.a. & 63.74 & 63.74 & n.a. & n.a. \\
\hline
\end{tabular}

Note:

$$
\text { 1) } \frac{d X_{i t}^{E}}{X_{i t}^{E}} / \frac{d e_{t}}{e_{t}}
$$

2) Hedging=1, if the firm is using forward exchange rate sales and purchases in 1997.

3) Average over all the Keiretsu firms in the industry.

4) Average over all the Non-Keiretsu firms in the industry.

5) Average over all the firms using financial hedging (foreign exchange sales and purchases) in the industry.

6) Average over all the firms not using financial hedging (foreign exchange sales and purchases) in the industry.

7) Coefficient on (keiretsu dummy) $\times\left(\right.$ Financing Constraint $w_{i t}{ }^{E}$ in (27)), and $t$-statistics in parenthesis. 
Table 6 Exchange Rate Elasticities of Exports when the Firm is Hedging Completely ${ }^{1)}$ (by Industry, in Percent)

\begin{tabular}{|l|c|c|c|c|}
\hline \multirow{2}{*}{ Industry } & \multicolumn{3}{|c|}{ Export Elasticity } \\
\hline Ordinary steel & Average & Median & Max & Min \\
\cline { 2 - 5 } Specialty steel & 0.742 & 0.139 & 3.861 & 0.062 \\
Boiler and turbine & 0.347 & 0.407 & 0.452 & 0.124 \\
Metal machinery & 0.032 & 0.033 & 0.033 & 0.032 \\
Textile machinery & 0.007 & 0.008 & 0.008 & 0.006 \\
Agricultural machinery & 0.005 & 0.005 & 0.005 & 0.005 \\
Construction machinery & 0.006 & 0.006 & 0.006 & 0.005 \\
Office machinery & 0.012 & 0.012 & 0.012 & 0.012 \\
Communication equipment & 0.030 & 0.030 & 0.030 & 0.027 \\
Musical instrument & 0.013 & 0.013 & 0.013 & 0.012 \\
Autos & 0.039 & 0.039 & 0.040 & 0.037 \\
Measuring equipment & 0.003 & 0.003 & 0.003 & 0.003 \\
Optical instrument & 0.000 & 0.000 & 0.001 & 0.000 \\
Watches & 0.029 & 0.029 & 0.029 & 0.029 \\
\hline
\end{tabular}

Note:
1) $\frac{d X_{i t}^{E}}{X_{i t}^{E}} / \frac{d e_{t}}{e_{t}}$ when $h_{i t}{ }^{E}=1$. 
Figure 1 The Exchange Rate, Hedging, and Cash Flow when $\alpha_{i t}>0$

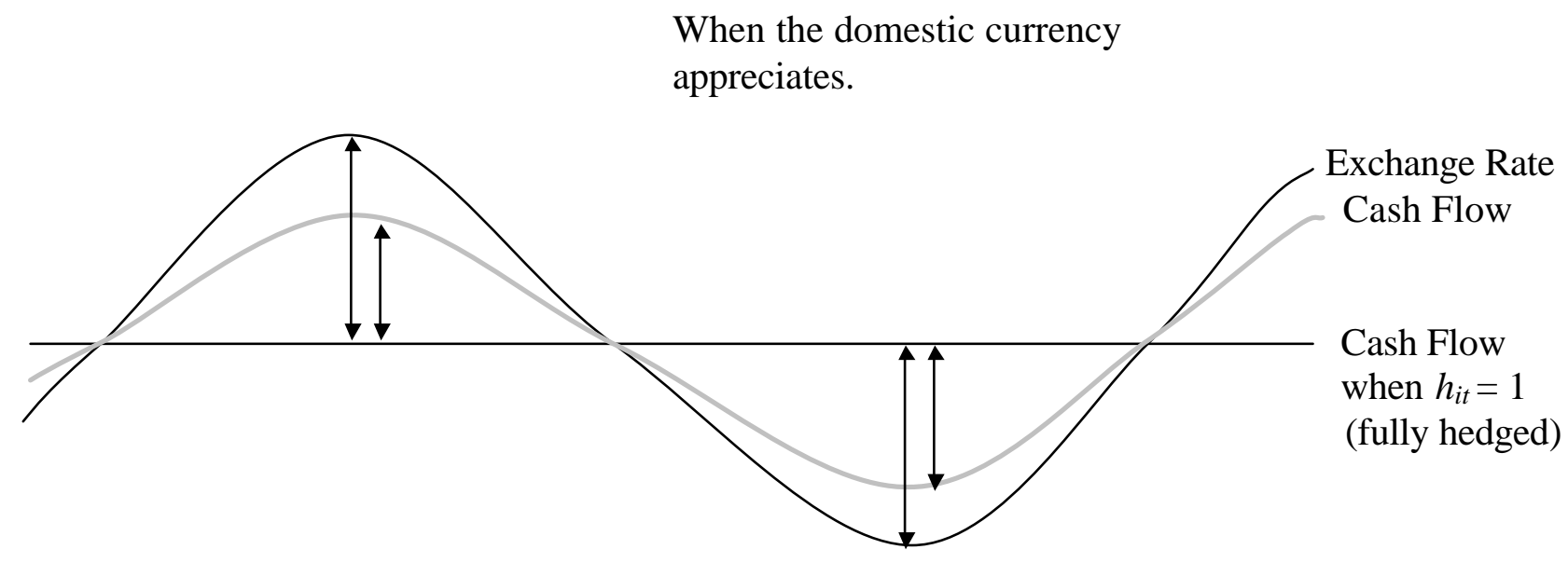

When the domestic currency

depreciates. 
Figure 2 The Exchange Rate, Hedging, and Cash Flow when $\alpha_{i t}<0$

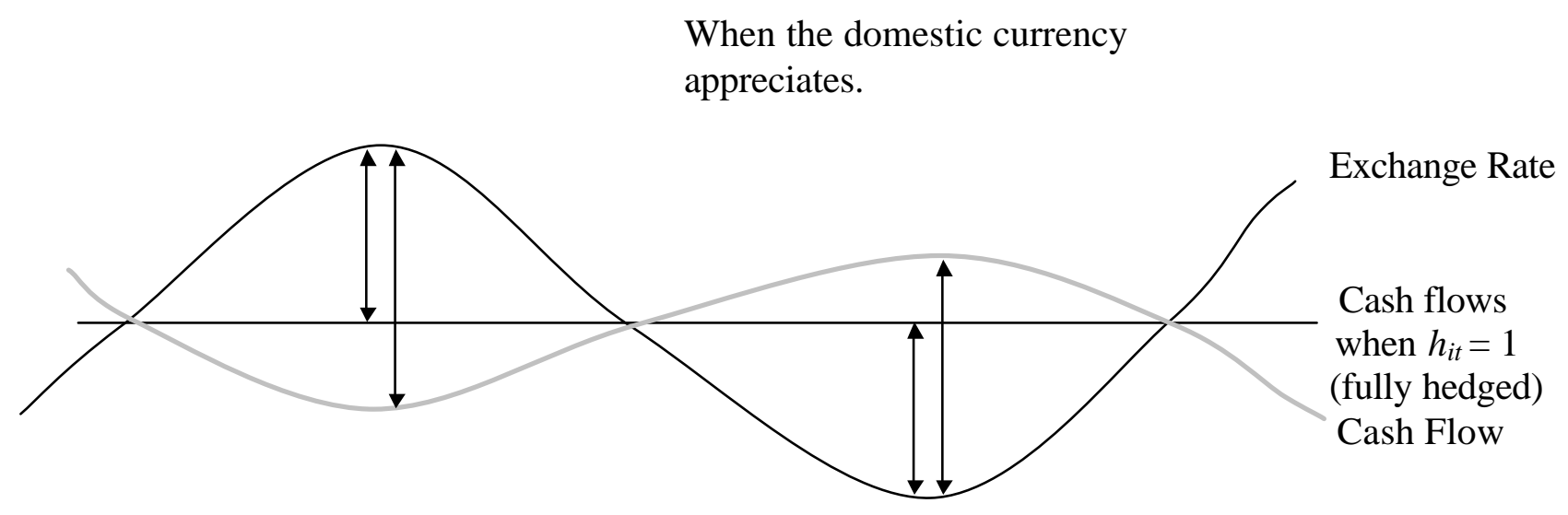

When the domestic currency

depreciates. 
Figure 3 Association of $\tilde{\alpha}_{i t}$ and Firm Export Elasticities

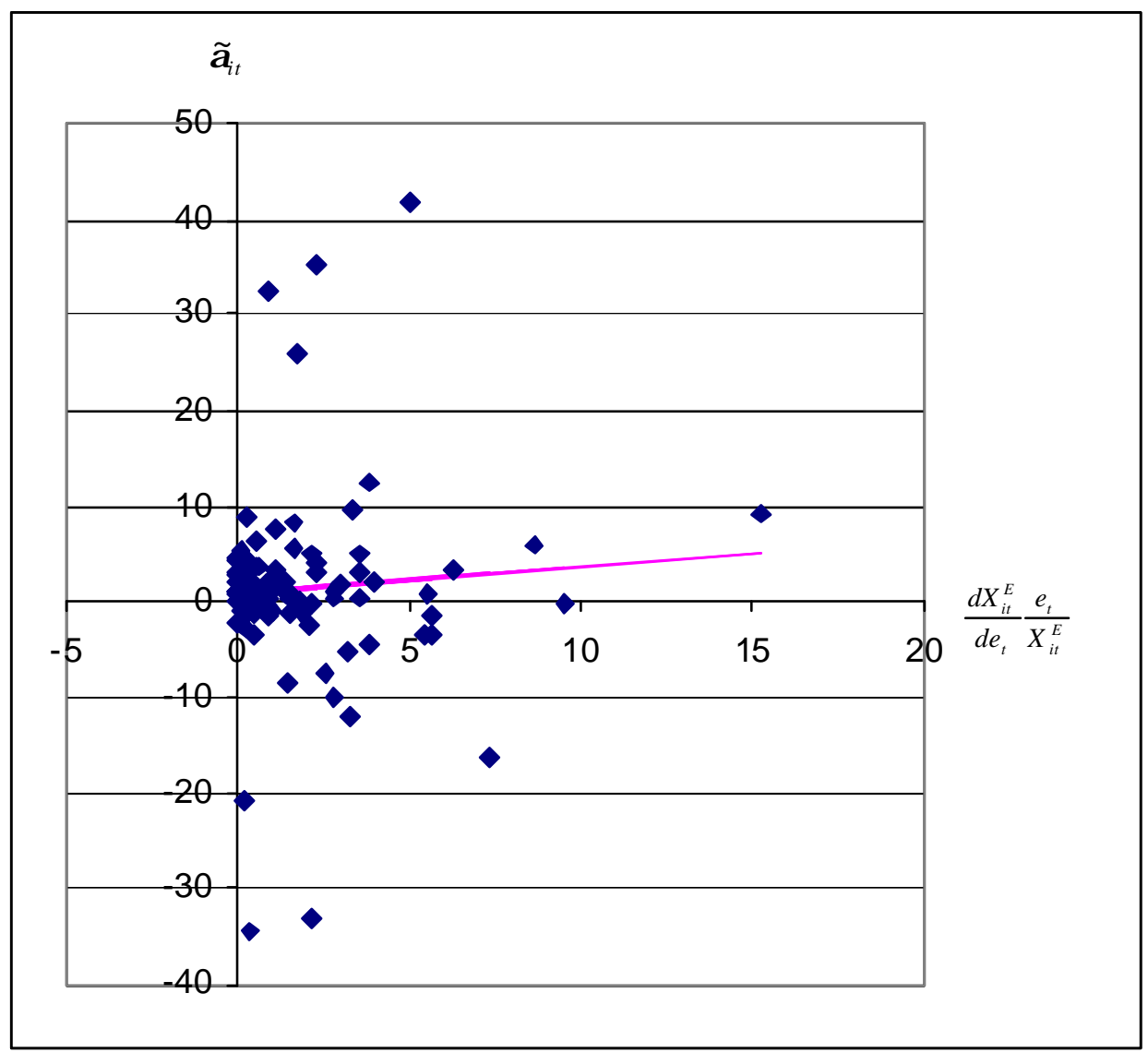

